\title{
Seasonal changes in Baltic Sea seston stoichiometry: the influence of diazotrophic cyanobacteria
}

\author{
Jakob Walve*, Ulf Larsson \\ Department of Systems Ecology, Stockholm University, 10691 Stockholm, Sweden
}

\begin{abstract}
We studied nutrient deficiency of Baltic Sea phytoplankton, as indicated by C:N:P ratios in filamentous $\mathrm{N}_{2}$-fixing (diazotrophic) cyanobacteria and size-fractions of seston. Samples were collected during an annual cycle in the NW Baltic proper (1998, Landsort Deep) and in 2 summers in the central Baltic proper (1997 and 1998, Gotland Basin). Generally, seston C:N:P ratios in the top $20 \mathrm{~m}$ were close to Redfield values. There was a transient increase in the C:N ratio at the end of the phytoplankton spring bloom (to $~ 9$ mol:mol), concomitant with the depletion of dissolved inorganic $\mathrm{N}$ (DIN), but not dissolved inorganic phosphorus (DIP), indicating that phytoplankton became N-limited at the end of the spring bloom. In early summer (May-June), seston C:N:P ratios indicated weak N limitation of the community of small phytoplankton. From June through summer, seston size-fractions $<10 \mu \mathrm{m}$ accumulated mainly C and N, resulting in a September peak in seston C:P and N:P ratios (201 and $23 \mathrm{~mol}: \mathrm{mol}$, respectively) in the surface water. This change occurred in parallel with an increase in $\mathrm{C}: \mathrm{P}$ and $\mathrm{N}: \mathrm{P}$ ratios of diazotrophic filamentous cyanobacteria to levels indicative of severe P limitation of cyanobacterial growth. This suggests that the cyanobacterial $\mathrm{P}$ demand and new $\mathrm{N}$ from their $\mathrm{N}_{2}$ fixation caused a weak P deficiency also in non-diazotrophs. However, the small increase in seston $\mathrm{N}: \mathrm{P}$, as well as a seston $\mathrm{C}: \mathrm{N}$ above the Redfield ratio, indicate that $\mathrm{N}$ and $\mathrm{P}$ are nearly colimiting for non-diazotrophs at the culmination of the cyanobacterial bloom in late summer.
\end{abstract}

KEY WORDS: Seston • Element ratios • Nutrient limitation • Stoichiometry • Baltic Sea • Cyanobacteria $\cdot$ Size fraction

\section{INTRODUCTION}

The elemental composition of oceanic seston (particulate matter) is considered to control ocean stoichiometry of $\mathrm{N}$ and $\mathrm{P}$, at least over long time-scales (Redfield et al. 1963, Falkowski \& Davis 2004, Klausmeier et al. 2008). Knowledge of the variability of seston elemental composition, and its controlling factors, is needed to understand the global cycling of N, P and C (Klausmeier et al. 2008). In marine seston, these elements generally occur in molar proportions close to $\mathrm{C}_{106}: \mathrm{N}_{16}: \mathrm{P}_{1}$, known as the Redfield ratio. This ratio has been widely implemented, e.g. for calculations of nutrient-based productivity and export, and to differentiate between $\mathrm{N}$ and $\mathrm{P}$ limitation of phytoplankton growth (e.g. Tyrrell 1999). The dissolved inorganic N:P ratio in oceanic deep-water is only slightly lower than the seston N:P ratio, mainly due to $\mathrm{N}$ losses by denitrification in oxygen-depleted zones (Deutsch et al. 2007). When mixed with surface waters, this $\mathrm{N}$ deficit stimulates $\mathrm{N}_{2}$ fixation, which balances the oceanic $\mathrm{N}$ budget (Karl et al. 2002, Deutsch et al. 2007).

In contrast to the low variability of oceanic seston stoichiometry, the elemental composition of cultured phytoplankton is highly flexible and depends on their growth rate and the N:P supply ratio (Klausmeier et al. 2008). Generally, P- and N-limited growth decrease cellular $\mathrm{P}$ and $\mathrm{N}$ content, respectively, giving high $\mathrm{C}: \mathrm{P}$ or C:N ratios. Near maximal growth rates are only possible at elemental compositions approaching the the Redfield ratio, which led Goldman et al. (1979) to propose that ocean phytoplankton growth rates must be near maximal. The close coupling between phytoplankton stoichiometry and growth rate has also been 
used to propose thresholds in phytoplankton elemental ratios for indicating nutrient limitation (Healey \& Hendzel 1980). However, under natural conditions, there is not necessarily a simple relationship between phytoplankton stoichiometry on the one hand, and nutrient availability, system productivity and phytoplankton biomass on the other. In a situation of low nutrient availability, severely nutrient-limited species may be outcompeted, and the growth rates of species dominating under these conditions may still be close to maximal (i.e. slightly nutrient limited), with element ratios near Redfield values (Goldman et al. 1979, Howarth 1988, Sommer 1989). Nevertheless, Hecky \& Kilham (1988) proposed the elemental composition of seston as a useful indicator of nutrient limitation and relative growth rates of phytoplankton communities, and this has been commonly used (e.g. Sommer 1991, Hecky et al. 1993, Elser et al. 1995, Hochstädter 2000, Lignell et al. 2003). Deviations from the Redfield ratio are more common in lakes than in marine systems, suggesting more severe or more frequent nutrient limitation, predominantly by $\mathrm{P}$, in lakes (Hecky \& Kilham 1988, Hecky et al. 1993, see also Elser et al. 2007). This is possibly a result of more frequent co-limitation by light in marine systems (Tett et al. 1985), and may also be influenced by differences between systems in nutrient supply ratios (Klausmeier et al. 2008).

In the present study, we investigated seasonal changes in the $\mathrm{C}, \mathrm{N}$ and $\mathrm{P}$ composition of seston in the brackish Baltic proper (salinity 6 to 8), the largest basin of the semi-enclosed, non-tidal, temperate Baltic Sea. Here, an already low dissolved inorganic N:P ratio (DIN:DIP) in winter (Granéli et al. 1990) decreases further during the phytoplankton spring bloom, which removes much of the DIN stored above the permanent halocline in winter, but leaves considerable amounts of DIP unused (Rahm et al. 2000, Larsson et al. 2001), clear evidence of an N-limited spring bloom. After the spring bloom, the formation of a seasonal thermocline in late spring/early summer isolates an intermediate water mass with a very low inorganic $\mathrm{N}: \mathrm{P}$ ratio (Sjöberg \& Larsson 1996), below the upper mixed layer and above the deeper, permanent halocline. Consequently, mixing events which add nutrients to the upper mixed layer will further drive phytoplankton towards $\mathrm{N}$ limitation, while atmospheric deposition, which is nearly devoid of P (Rolff et al. 2008), will to some extent relax the $\mathrm{N}$ deficit (Larsson et al. 2001).

The low DIN:DIP ratio in the winter is an important factor causing the recurrent summer blooms of diazotrophic ( $\mathrm{N}_{2}$-fixing) filamentous cyanobacteria in the Baltic proper (Niemi 1979, Kahru et al. 2007). These blooms are dominated by Nodularia spumigena and Aphanizomenon sp., and recent estimates suggest that their $\mathrm{N}_{2}$ fixation contributes several times more $\mathrm{N}$ than previously estimated, and thus sustains much of the net production by the summer plankton community (Larsson et al. 2001, Wasmund et al. 2005). Due to a substantial decrease in cellular $\mathrm{P}$ storage during the bloom (Larsson et al. 2001, Walve \& Larsson 2007), the $\mathrm{N}_{2}$ fixation is greater than would be indicated by estimates using the DIP supply to the upper mixed layer and the Redfield N:P ratio for cyanobacterial growth. In addition, $\mathrm{N}$ leakage from actively growing cyanobacterial cells may be an important $\mathrm{N}$ source for nondiazotrophs (Glibert \& Bronk 1994, Rolff et al. 2007). We hypothesize that inputs of new $\mathrm{N}$ from $\mathrm{N}_{2}$-fixing cyanobacteria will alleviate the $\mathrm{N}$ deficiency of nondiazotrophs, thereby increasing the community $\mathrm{P}$ demand until low $\mathrm{P}$ availability eventually reduces the growth rates of all phytoplankton. In the present study we used the elemental composition of size-fractionated seston to investigate plankton nutrient deficiency during an annual study in the northern Baltic proper (Landsort Deep) and on 2 summer cruises to the eastern Gotland Basin in the central Baltic proper.

\section{MATERIALS AND METHODS}

Sampling stations. In 1998, we sampled the Landsort Deep Station (Stn BY31, 58 $35^{\prime}$ N, $18^{\circ} 14^{\prime} E_{\text {; Fig. }}$ ) in the NW Baltic proper weekly (size-fractionation of

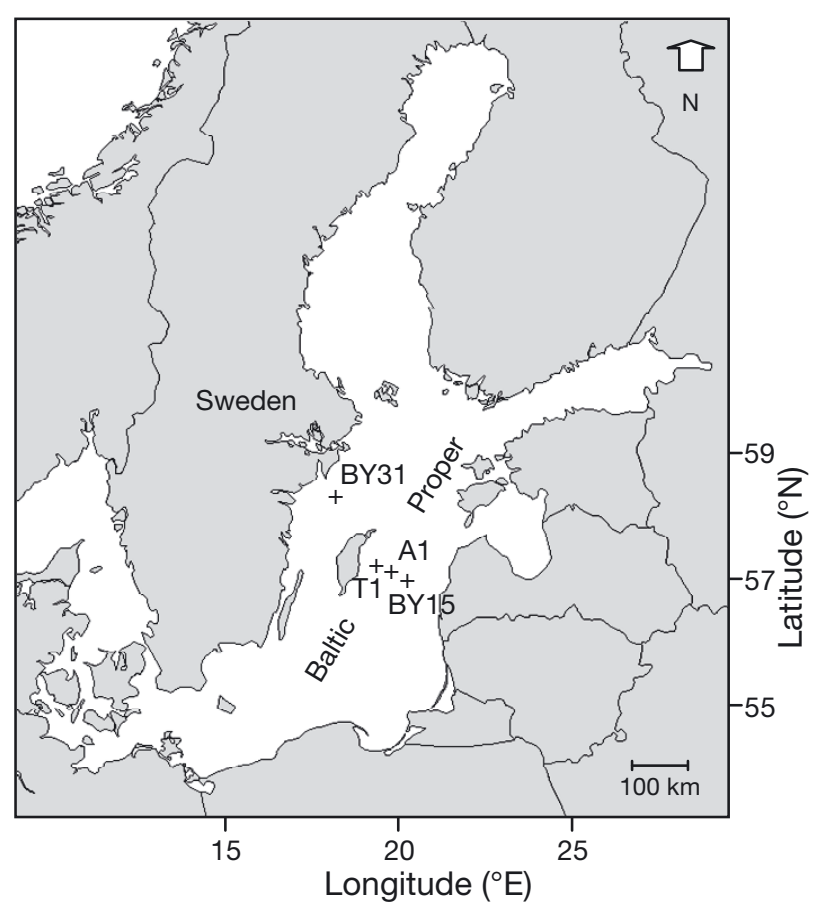

Fig. 1. Sampling stations (+) in the Baltic proper, the main basin in the Baltic Sea 
seston biweekly) during the spring bloom, biweekly in May to October and monthly in winter. In addition, 3 stations in the eastern Gotland Basin were sampled in 2 summers (1997: 30 \& $31 \mathrm{Jul}$ and 1 \& 6 Aug, Stn A1, $57^{\circ} 27^{\prime} \mathrm{N} 19^{\circ} 42^{\prime} \mathrm{E}_{;} 1998: 7 \mathrm{Aug}, \mathrm{Stn} \mathrm{T} 1,57^{\circ} 36^{\prime} \mathrm{N}$

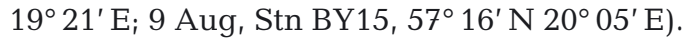

Salinity, temperature and water column stratification. Salinity, temperature and density were measured with a CTD probe (SST Memory probe, Sea \& Sun Technology), with readings every $0.5 \mathrm{~m}$. Brunt-Väisälä buoyancy frequencies, $N^{2}=-g / \rho(\delta \rho / \delta z)$, were calculated by obtaining mean density $(\rho)$ and the change in density with depth $(\delta \rho / \delta z)$ over 3 successive depths. The Brunt-Väisälä frequency represents the strength of the density stratification and, therefore, the stability of the water column. Its frequency is maximal at the depth of maximum stability, and this depth was selected to represent the seasonal pycnocline depth.

Inorganic nutrients. At the Landsort Deep station, we collected water from $0,5,10,15,20,25,30,40,50$, 60 and $80 \mathrm{~m}$ depths with serial 51 Niskin bottles (Hydrobios). Samples were filtered (0.45 $\mu \mathrm{m}$ membrane filter, Millipore) into $12 \mathrm{ml}$ plastic vials and kept refrigerated until analysed within $24 \mathrm{~h}$. DIP and DIN $\left(\mathrm{NH}_{4}{ }^{+}+\mathrm{NO}_{2}{ }^{-}+\mathrm{NO}_{3}{ }^{-}\right)$were determined by standard flow injection analysis (slightly modified QuikChem ${ }^{\circledR} 8000$ Methods: 31-115-01-3-A, 31-107-04-1-A and 31-10706-1-A, Lachat Instruments; detection limits: $\mathrm{PO}_{4}{ }^{3-}$, $16 \mathrm{nmol} \mathrm{l}^{-1} ; \mathrm{NH}_{4}{ }^{+}, 36 \mathrm{nmol} \mathrm{l}^{-1} ; \mathrm{NO}_{2}{ }^{-}+\mathrm{NO}_{3}{ }^{-}, 14 \mathrm{nmol} \mathrm{l}^{-1}$ ).

Seston size-fractionation. Between 500 and $1500 \mathrm{l}$ of water were pumped from $5 \mathrm{~m}$ depth (membrane pump Sandpiper PB1 $\frac{1}{2}$-A, water flow $501 \mathrm{~min}^{-1}$, except in 1997 when a peristaltic Millipore pump was used [ 10 1 $\min ^{-1}$ ]) through a series of 4 plankton nets of decreasing mesh size $(90,41,20$ and $10 \mu \mathrm{m}$, each $1 \mathrm{~m}$ long with $0.5 \mathrm{~m}$ opening) placed in a $200 \mathrm{l}$ barrel on deck. Water for analysis of total (unfractionated) seston was collected regularly directly from the intake, while $<10 \mu \mathrm{m}$ filtrate was collected from the barrel outlet, located near the top of the barrel to keep the nets submersed during filtration. When retrieved, the nets were gently shaken and rinsed from the outside with $<10 \mu \mathrm{m}$ water. The loss of particles from the nets during this process should contribute to the $<10 \mu \mathrm{m}$ fraction. To compensate for this bias, water was added from the barrel to the $<10 \mu \mathrm{m}$ filtrate according to the total pumped volume relative to the barrel volume. Subsamples $(<201)$ of the the $<10 \mu \mathrm{m}$ filtrate were gravity filtered through a $3 \mu \mathrm{m}$ Nucleopore filter (Ø $293 \mathrm{~mm}$ ). At the stations east of Gotland we also collected the filtrate from a $1 \mu \mathrm{m}$ Nucleopore filter (Ø $293 \mathrm{~mm}$ ).

In addition, we analysed total (unfractionated) seston elemental composition in pooled samples from Landsort Deep, collected from 0, 5, 10, 15 and $20 \mathrm{~m}$ depths with serial 51 Niskin bottles.
Particles in intact seawater and in the $<10,<3$ and $<1 \mu \mathrm{m}$ filtrates were collected on acid-washed, precombusted $\left(400^{\circ} \mathrm{C}, 2 \mathrm{~h}\right)$ Whatman GF/F-filters $(\varnothing$ $25 \mathrm{~mm}$, nominal pore size $0.7 \mu \mathrm{m})$. Filtration suction was maintained at $-25 \mathrm{~mm} \mathrm{Hg}$. The volumes filtered depended on the particle concentration in the water, and were usually 0.5 to 11 for the unfractionated water samples, 0.7 to 1.21 for the $<10 \mu \mathrm{m}$ filtrate, 1 to 21 for the $<3 \mu \mathrm{m}$ filtrate and 2.5 to 31 for the $<1 \mu \mathrm{m}$ filtrate. The amount of material collected on the GF/F filters was similar for all size fractions. Two sets of triplicate filters (duplicate for 0 to $20 \mathrm{~m}$ pooled samples and from the 1997 cruise) were prepared for C, N and P analyses (see below). Filters were rinsed with $\mathrm{NaCl}$ solution $(0.7 \%)$ and stored frozen $\left(-20^{\circ} \mathrm{C}\right)$ in Eppendorf vials. Blanks were prepared by filtering a small volume (0.3 to 0.5 l) of Milli-Q water and rinsing with $\mathrm{NaCl}$ solution. Prior to analysis, filters were dried overnight at $60^{\circ} \mathrm{C}$.

Seston collected on the nets was diluted in filtered $(\mathrm{GF} / \mathrm{F})$ seawater to a known volume $\left(A_{\mathrm{vol}}\right)$ and aliquots $\left(B_{\mathrm{vol}}\right)$ filtered onto GF/F filters, as above. The seston concentration in each size fraction was calculated as $\left(A_{\mathrm{vol}} \times C / B_{\mathrm{vol}}\right) /$ pumped volume, where $C$ is $\mu \mathrm{mol} \mathrm{C}$ on the filter.

The sum of $\mathrm{C}, \mathrm{N}$ and $\mathrm{P}$ concentrations in the $<10$, $10-20,20-40,40-90$ and $>90 \mu \mathrm{m}$ size fractions usually agreed well with the concentrations found in the unfractionated water. However, on a few occasions during the spring bloom, $\mathrm{P}$, and to a lesser extent $\mathrm{N}$, was lost from the larger size fractions, as indicated by higher $\mathrm{C}: \mathrm{N}$ and $\mathrm{C}: \mathrm{P}$ ratios than in unfractionated water, while the smallest fractions had similar ratios.

Collection of cyanobacteria. Data on cyanobacterial elemental composition at the Landsort Deep in 1998 are from Larsson et al. (2001). In short, we performed vertical hauls using a $90 \mu \mathrm{m}$ WP2 zooplankton net, from the seasonal pycnocline (when absent from $15 \mathrm{~m}$ ) to the surface. Zooplankton were removed in a light trap (a black funnel illuminated from below), where they concentrated at the bottom, while buoyant cyanobacteria floated to the top. After rinsing on a plankton net, subsamples of cyanobacteria were dried to constant weight at $60^{\circ} \mathrm{C}$ (ca. $3 \mathrm{~d}$ ).

Analyses of seston and cyanobacteria. Seston $\mathrm{C}$ and $\mathrm{N}$ was analyzed on a Leco CHN-analyzer (CHN-900, 600-800-300, EDTA as standard). Seston C, N and P are equivalent to particulate organic fractions, as inorganic fractions are negligible. Filters were folded and wrapped in tin foils for $\mathrm{C}$ and $\mathrm{N}$ analysis. Samples for $\mathrm{P}$ analysis were combusted $2 \mathrm{~h}$ at $500^{\circ} \mathrm{C}$ in $15 \mathrm{ml}$ glass tubes and digested in $6 \mathrm{ml}$ persulfate solution (50 g $\mathrm{K}_{2} \mathrm{~S}_{2} \mathrm{O}_{8} \mathrm{l}^{-1}+30 \mathrm{ml} \mathrm{H}_{2} \mathrm{SO}_{4} \mathrm{l}^{-1}, 1 \mathrm{~h}, 120^{\circ} \mathrm{C}$ ). After addition of $4 \mathrm{ml} 1.6 \mathrm{M} \mathrm{NaOH}$, the samples were analyzed for molybdate-reactive orthophosphate with flow injec- 
tion (Lachat Instruments, slightly modified QuickChem Method 31-115-01-3-A). Blanks were carried through the same procedure. Standards were prepared by adding stock phosphate solution to vials before digestion.

Chlorophyll a. Subsamples of fractionated water (see above) were filtered on GF/F-filters ( $\varnothing 77 \mathrm{~mm}$ ), which were kept frozen $\left(-20^{\circ} \mathrm{C}\right)$ until analysis. After grinding the filter with a Teflon piston (Millipore) in $90 \%$ acetone, and extraction for $2 \mathrm{~h}$ at room temperature, chlorophyll a (chl a) was determined spectrophotometrically (SIS-standard SS028146).

Phytoplankton. On each sampling occasion an integrated phytoplankton sample (0 to $20 \mathrm{~m}$ ) was collected with a plastic tube (inner diameter $1.9 \mathrm{~cm}$ ). The lower end, equipped with a weight, was gently lowered to $20 \mathrm{~m}$ depth; the tube was then closed at the upper end, retrieved and emptied into a bucket. A $200 \mathrm{ml}$ subsample, siphoned from the bucket while stirring, was preserved with $0.8 \mathrm{ml}$ of Lugol's iodine $\left(\mathrm{I}_{2} \mathrm{KI}\right)$ solution supplemented with acetic acid. Phytoplankton samples were also taken from the filtrates of the different sizefractions. After settling in a 10 to $50 \mathrm{ml}$ settling chamber, phytoplankton were counted using a Nikon inverted microscope with phase contrast (10 to $40 \times$ objective), according to the HELCOM (1988) guidelines. This method counts all phytoplankton cells larger than about $2 \mu \mathrm{m}$, including colonial, but not single-celled, picocyanobacteria. Biomasses were estimated by multiplying the cell numbers with speciesspecific mean cell volumes, determined from measurements. Vacuoles were excluded from diatom cell volumes. A factor of $0.11 \mathrm{pg} \mathrm{C} \mathrm{mm}^{-3}$ was used to convert volume to carbon, except for armoured dinoflagel-



Statistical analyses. Statistical tests were performed with Statistica for Windows (Statsoft). The non-parametric Wilcoxon matched pairs test was used to analyse differences in seston stoichiometry between depths. The Mann-Whitney $U$-test was used to compare Gotland Basin samples from different years. Linear regression was used to relate seston stoichiometry to cyanobacterial stoichiometry.

\section{RESULTS}

\section{$\mathbf{N}_{2}$-fixing cyanobacteria at Landort Deep}

In 1998, Aphanizomenon sp. was present year-round at the Landsort Deep station, and it dominated the biomass of filamentous $\mathrm{N}_{2}$-fixing cyanobacteria (Larsson et al. 2001; Fig. 2A). Significant quantities of Nodularia spumigena occurred only in July and early August, and other filamentous genera were virtually absent.
During the bloom, filamentous $\mathrm{N}_{2}$-fixing cyanobacteria increased their share from $<2$ to $42 \%$ of the phytoplankton biomass derived from conventional microscopic counts, which included colonial but not singlecelled picocyanobacteria (Fig. 2A).

The C:N:P ratios of the filamentous $\mathrm{N}_{2}$-fixing cyanobacteria in 1998 were presented in Larsson et al. (2001) and are described briefly here, with information on dry weight specific element content added. In winter and spring, the cellular P content was high (up to $3.4 \%$ of dry weight; Fig. 2B), resulting in low C:P and N:P ratios (32 and 7 mol:mol; Fig. 2C). The P content decreased during June and July, and the lowest P content $(0.3 \%$ of dry weight) and highest C:P (423) and N:P ratios (65) in the filamentous cyanobacteria were found in the early September biomass peak, consisting of $80 \%$ Aphanizomenon sp. and $20 \%$ Nodularia spumigena (Fig. 2A, C). After the peak, the C:P and N:P ratios in Aphanizomenon sp. remained relatively high (Fig. 2C)

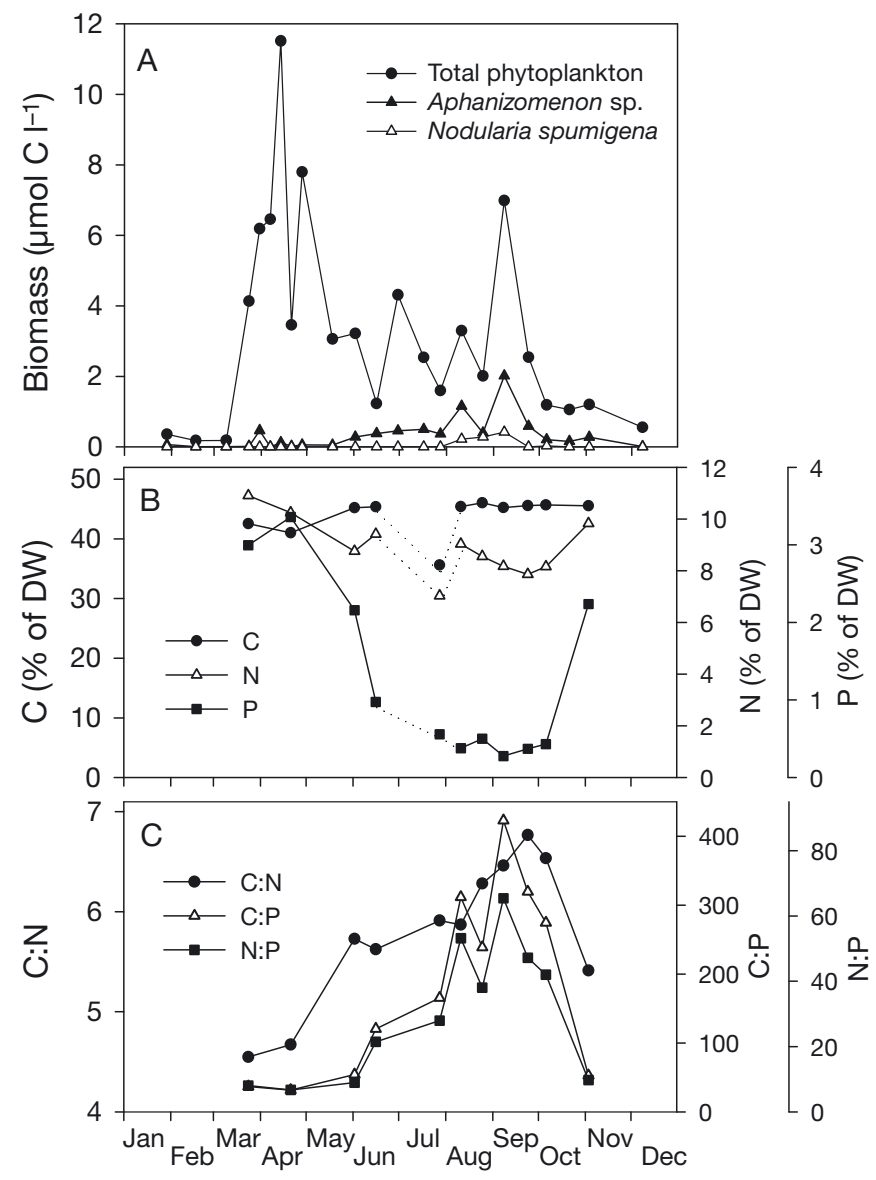

Fig. 2. Landsort Deep station (BY31) in 1998. (A) Biomass $\left(\mu \mathrm{mol} \mathrm{C} \mathrm{^{-1 }}\right.$ ) estimated from microscopic counts of total phytoplankton (excluding single-celled picocyanobacteria) and the filamentous $\mathrm{N}_{2}$-fixing cyanobacteria Aphanizomenon sp. and Nodularia spumigena; (B) C, N and P content (\% of dry weight $[\mathrm{DW}])$ of these cyanobacteria; and (C) their molar $\mathrm{C}: \mathrm{N}: \mathrm{P}$ ratios 
until the DIP concentration increased in the autumn, when the Aphanizomenon sp. cells largely restored their cellular $\mathrm{P}$ content to that of the previous winter (Fig. 2B). The C:N ratio was much less variable and increased from well below the Redfield ratio of 6.625 in spring to just below the Redfield ratio at the time of the biomass peak (Fig. 2C). On 28 July the $\mathrm{C}$ and $\mathrm{N}$ contents were low, probably due to incomplete removal of salt from the samples (Fig. 2B), but the C:N ratio appeared reasonable compared to other sampling occasions (Fig. 2C).

\section{Dissolved nutrients and seston stoichiometry at Landsort Deep}

Compared to the Redfield ratio, there was a clear excess of DIP relative to DIN in winter (Fig. 3A). In late March, phytoplankton biomass (Fig. 2A) and seston C, $\mathrm{N}$ and $\mathrm{P}$ concentrations (Fig. 4A-C) increased rapidly



Fig. 3. Landsort Deep station (BY31) in 1998. (A) Concentrations of dissolved inorganic nitrogen (DIN) and phosphorus (DIP) ( $\left.\mu \mathrm{mol} \mathrm{l}^{-1}\right)$, scaled according to the Redfield ratio of 16; (B) stability of stratification as maximum Brunt-Väisälä frequency $\left(N^{2}\right)$ and thermocline depth as depth of maximum $N^{2}$ and (C) temperature and salinity at $5 \mathrm{~m}$ until DIN was depleted in late April, but more than a third of the DIP winter storage remained available in the top $20 \mathrm{~m}$ of the water column. During most of the spring bloom, the seston $\mathrm{C}: \mathrm{N}$ ratio was only slightly higher, the C:P ratio was close to, and the N:P ratio was slightly below the Redfield ratio (Fig. 4D-F). At the seston peak in late April we recorded the highest seston $\mathrm{C}: \mathrm{N}$ ratio $(\sim 9)$ in the top $20 \mathrm{~m}$ of the water mass (Fig. 4D). The $5 \mathrm{~m}$ sample, collected every second week, was missing on this occasion (Figs. 4 \& 5), but in early May, 2 wk later, the $5 \mathrm{~m}$ sample had a similar C:N ratio to the 0 to $20 \mathrm{~m}$ sample.

During the initial phase of the spring bloom, much of the seston was found in size fractions larger than $10 \mu \mathrm{m}$, with a shift towards smaller particles as the bloom progressed (Fig. 5). This was mirrored by a succession from diatoms to dinoflagellates. From midApril until the seston peak in late April, dinoflagellates made up ca. $80 \%$ of phytoplankton C (data not shown). The chl a concentration peaked earlier than seston $C$ (Fig. 6), resulting in a low C:chl a weight ratio in early spring and a higher ratio towards the end of the spring bloom (Fig. 6).

Following the collapse of the spring bloom, there was an increase in the $<3 \mu \mathrm{m}$ size fraction of seston (Fig. 5) and chl a (Fig. 6), indicating dominance by small phytoplankton in May and June. The C:N ratio in seston $<3 \mu \mathrm{m}$ was close to the Redfield ratio in midMay, increased to ca. 8 in early June and then declined in mid-June, concomitant with an increase in C:P and $\mathrm{N}$ :P ratios. During this period, DIP decreased gradually and by mid-June was finally depleted in the surface mixed layer, while DIN was continuously close to or below the detection limit down to at least $40 \mathrm{~m}$ depth (Fig. 3A, deep-water data not shown).

Throughout summer, the $<3 \mu \mathrm{m}$ fraction generally held about half of the seston, and more than $80 \%$ of the seston passed a $10 \mu \mathrm{m}$ filter (Fig. 5A). Thus size fractions $>10 \mu \mathrm{m}$ held relatively little $\mathrm{C}$, and were dominated by zooplankton and filamentous cyanobacteria in the $>90 \mu \mathrm{m}$ size fraction. In summer, the highest concentrations of $\mathrm{C}$ and $\mathrm{N}$, but not $\mathrm{P}$, in unfractionated seston coincided with the peak in diazotroph biomass (Figs. 2B \& 4A-C). As a result, seston C:P and N:P ratios at $5 \mathrm{~m}$ increased from June (Fig. 4E, F) until early September. In seston from the top $20 \mathrm{~m}$, the increase was smaller, indicating less $\mathrm{C}$ and $\mathrm{N}$ accumulation in the lower part of the $0-20 \mathrm{~m}$ depth interval (Fig. 4). The C:P and N:P ratios in the $<3 \mu \mathrm{m}$ and the $<10 \mu \mathrm{m}$ fractions (Fig. 5E, F) followed the pattern of the unfractionated seston in summer and also correlated with the cyanobacterial C:P and N:P ratios (Table 1). C:P and $\mathrm{N}: \mathrm{P}$ ratios of seston $<10 \mu \mathrm{m}$ peaked at higher values than in the seston $<3 \mu \mathrm{m}$ fraction (Fig. 5). C:P and N:P ratios of the 3-10 $\mu \mathrm{m}$ fraction (calculated from the dif- 

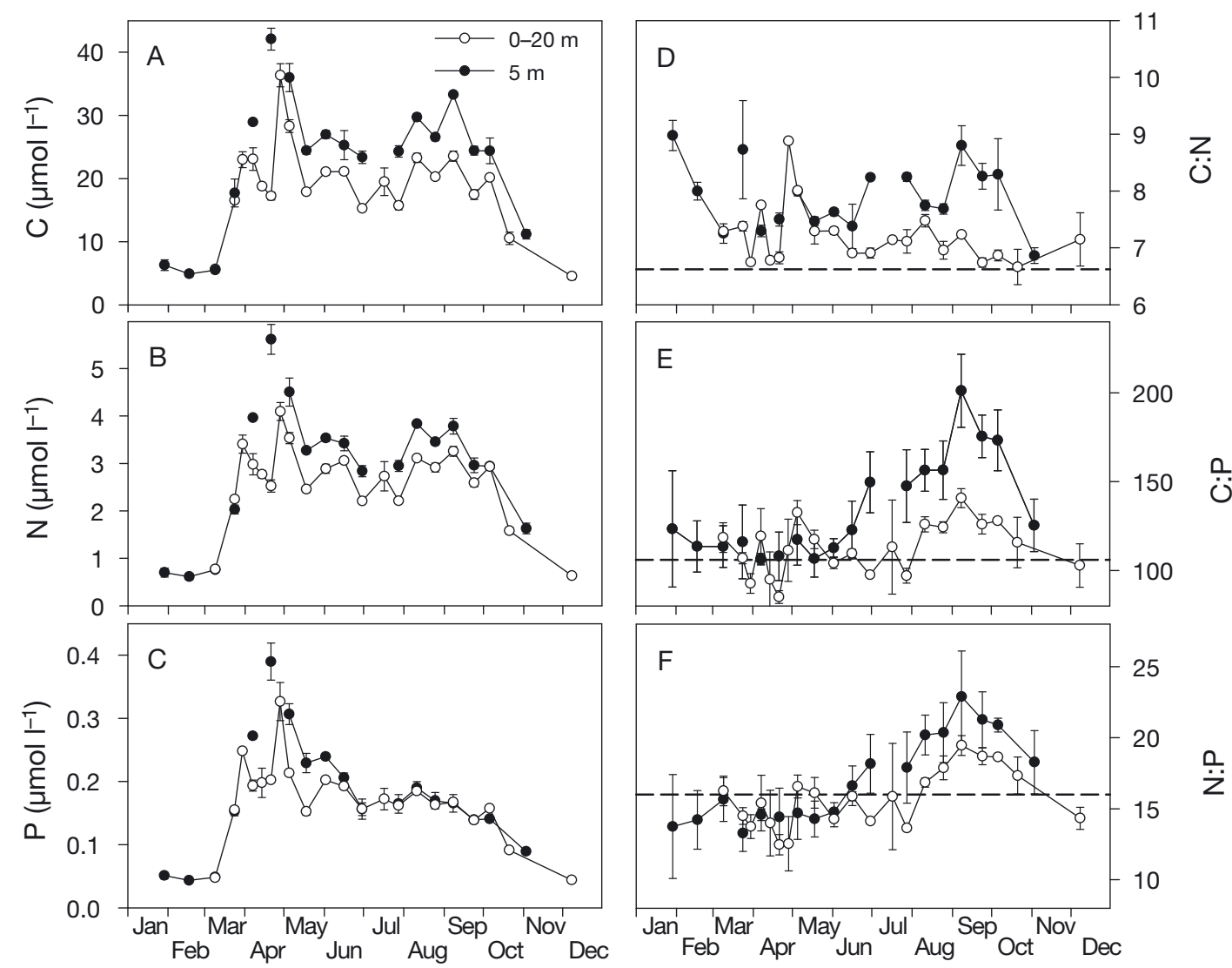

Fig. 4. Landsort Deep station (BY31) in 1998. (A-C) C, N and P concentrations ( $\mu \mathrm{mol} \mathrm{l}^{-1}$ ) and (D-F) molar C:N:P ratios of total seston from $5 \mathrm{~m}$ depth $(\bullet)$ and integrated from 0-20 m depth (O). Horizontal lines show Redfield ratios. Error bars are (A-C) SD of 3 replicate analyses at $5 \mathrm{~m}$ and range of 2 replicates at $0-20 \mathrm{~m}$, and (D-E) maximum and minimum ratios calculated from averages $\pm \mathrm{SD}(5 \mathrm{~m})$, or highest and lowest values of the range $(0-20 \mathrm{~m})$

ference between $<10$ and $<3 \mu \mathrm{m}$ concentrations) were near Redfield values in early summer (mean $\pm \mathrm{SD}$, $140 \pm 22$ and $15.5 \pm 2.6$, respectively, $\mathrm{n}=4$ ) and increased in late summer $(217 \pm 43,21.7 \pm 5.3, \mathrm{n}=5)$.

As in spring, C:N ratios in summer varied over a fairly limited range (6.9 to 9; Fig. 4D). C:N ratios were higher at $5 \mathrm{~m}$ than in the $0-20 \mathrm{~m}$ layer $(\mathrm{p}<0.01$, Wilcoxonmatched pairs test, from 18 May onwards), and showed a slight tendency to increase as summer progressed, which was not the case in the 0-20 m samples (Fig. 4D). The highest C:N ratio was found in the 3-10 $\mu \mathrm{m}$ fraction (mean $\pm \mathrm{SD}, 9.7 \pm 1.27, \mathrm{n}=9 ; 9.3 \pm 0.43$ if 1 outlier is excluded). The C:N ratio in the $>10 \mu \mathrm{m}$ fraction $(6.5 \pm$ 1.54), calculated as difference between the unfractionated total seston and $<10 \mu \mathrm{m}$ fraction, was clearly lower than the C:N ratio in the $3-10 \mu \mathrm{m}$ size fraction. This value for the $>10 \mu \mathrm{m}$ fraction was consistent with the $\mathrm{C}: \mathrm{N}$ ratio calculated from the summed net fractions $>10 \mu \mathrm{m}(10-20,20-40,40-90,>90 \mu \mathrm{m}) \quad(=6.8 \pm 0.5)$, which were dominated $(44 \pm 19 \%)$ by the fraction $>90 \mu \mathrm{m}(\mathrm{C}: \mathrm{N}=5.5 \pm 0.5)$. The $90 \mu \mathrm{m}$ fraction consisted of a mixture of zooplankton (expected $\mathrm{C}: \mathrm{N} \sim 4.6$, Walve \& Larsson 1999) and cyanobacteria $(\mathrm{C}: \mathrm{N} \sim 6)$.

\section{Estimates of biomass in seston at Landsort Deep}

Conventional microscopic counts (0-20 m integrated samples, Fig. 2A) indicated that, on average, $20 \%$ (range $=6$ to $61 \%$ ) of the seston $\mathrm{C}$ was phytoplankton biomass (this includes colonial, but not single-celled picocyanobacteria). Phytoplankton biomass contributed on average $30 \%$ (20 to $61 \%$ ) of total seston C in spring, $17 \%$ (6 to $28 \%$ ) in early summer, $15 \%$ (10 to $30 \%$ ) in late summer. Single-celled autotrophic picoplankton were not counted, but their biomass can be estimated roughly from the chl a content of the $<3 \mu \mathrm{m}$ fraction at $5 \mathrm{~m}$ depth. Assuming a rather conservative C:chl a ratio of 40 (Calvo-Díaz et al. 2008) and a similar contribution of the $<3 \mu \mathrm{m}$ fraction in the integrated as in the $5 \mathrm{~m}$ sample $(\sim 10 \%$ of total chl $a$ in spring, $54 \%$ in early summer and $45 \%$ in late summer), picoplankton contributed approximately $8 \%$ of total seston $\mathrm{C}$ in spring and $15 \%$ in summer. $\mathrm{C}$ from heterotrophic bacteria (data from Johansson et al. 2004) accounted for an additional $9 \%$ (3.5 to $17 \%)$, with the lowest value in spring ( 3.5 to $5 \%$ ), intermediate in early summer ( 6.5 to $11 \%$ ) and highest in late summer (9.2 to $16 \%)$. Irre- 

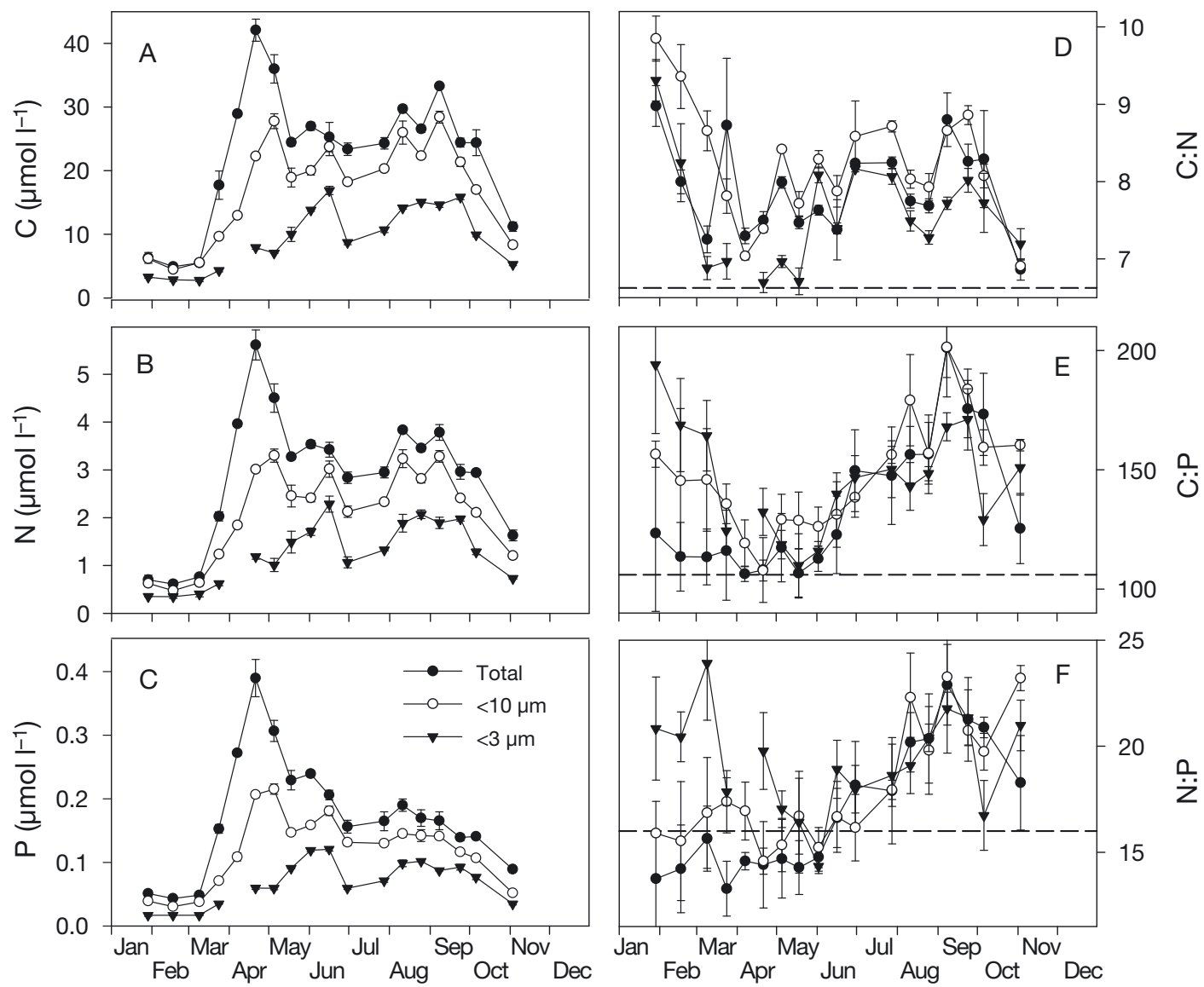

20

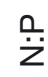

15

Fig. 5. Landsort Deep station (BY31) in 1998. (A-C) C, N and P concentrations ( $\mu \mathrm{mol}^{-1}$ ) and (D-F) molar C:N:P ratios of seston size fractions from $5 \mathrm{~m}$. Horizontal lines show the Redfield ratios. Error bars as in Fig. 4 for $5 \mathrm{~m}$ depth


Fig. 6. Landsort Deep station (BY31) in 1998. Chlorophyll a (chl $a, \mu g \mathrm{l}^{-1}$ ) in (A) total integrated seston samples from 0-20 m and (B) seston size fractions at $5 \mathrm{~m}$ depth. C:chl a ratios (w/w) in (C) integrated seston samples from 0-20 $\mathrm{m}$ and (D) seston size fractions at $5 \mathrm{~m}$ depth 
Table 1. Regression statistics for elemental ratios in filamentous cyanobacteria (independent variable) and seston size fractions (dependent variable). Values included are from summer: 2 June to 24 September (no cyanobacterial data 18 May), $\mathrm{n}=7$

\begin{tabular}{|llcc|}
\hline $\begin{array}{l}\text { Cyanobacteria } \\
\text { Size fraction }\end{array}$ & Equation & $\mathrm{r}^{2}$ & $\mathrm{p}$ \\
\hline $\mathrm{C}: \mathrm{N}$ & & & \\
$<3 \mu \mathrm{m} \mathrm{C:N}$ & $y=0.12 x+7.0$ & 0.02 & $\mathrm{~ns}$ \\
$<10 \mu \mathrm{m} \mathrm{C:N}$ & $y=0.59 x+4.7$ & 0.37 & $\mathrm{~ns}$ \\
Total C:N & $y=0.80 x+3.1$ & 0.47 & $\mathrm{~ns}$ \\
C:P & & & \\
$<3 \mu \mathrm{m} \mathrm{C:P}$ & $y=0.12 x+120$ & 0.70 & $<0.05$ \\
$<10 \mu \mathrm{m} \mathrm{C:P}$ & $y=0.21 x+113$ & 0.98 & $<0.001$ \\
Total C:P & $y=0.23 x+101$ & 0.93 & $<0.001$ \\
N:P & & & \\
$<3 \mu \mathrm{m} \mathrm{N}: \mathrm{P}$ & $y=0.11 x+15.3$ & 0.69 & $<0.05$ \\
$<10 \mu \mathrm{m} \mathrm{N}: \mathrm{P}$ & $y=0.15 x+13.8$ & 0.99 & $<0.00001$ \\
Total N:P & $y=0.14 x+13.9$ & 0.93 & $<0.001$ \\
\hline
\end{tabular}

spective of season, $\sim 40 \%$ of the seston C could therefore be attributed to phyto- and bacterioplankton.

\section{Eastern Gotland Basin in the summers of 1997 and 1998}

Weather conditions differed greatly between the 2 summer cruises to the eastern Gotland Basin. The summer of 1997 was warm and calm, while that of 1998 was cold and windy, with water temperatures in the top $10 \mathrm{~m}$ around $19^{\circ} \mathrm{C}$ in 1997 and $15^{\circ} \mathrm{C}$ in 1998 . The mixed layer depth was $\sim 15 \mathrm{~m}$ in both years but the stratification was weaker in 1998. In general, the relative particle size distribution and element composition was similar between stations and years, the main difference being a higher seston concentration in the $<10 \mu \mathrm{m}$ size fraction in 1997 (Fig. 7). Seston concentrations were low in all fractions $>10 \mu \mathrm{m}$, except $>90 \mu \mathrm{m}$, which included cyanobacteria and zooplankton. The $\mathrm{C}: \mathrm{N}$ ratios were near the Redfield ratio in the smallest and largest particles, and above the Redfield ratio in particles of intermediate sizes. C:P and N:P ratios increased with particle size from near Redfield ratios in the smallest fraction to several times the Redfield ratios in the largest size fractions (Fig. 7). For size fractions $>10 \mu \mathrm{m}$, this was at least partly due to the presence of filamentous cyanobacteria, since microscopic examination showed that they contributed approximately $60 \%$ of the C content in both the 40-90 and $>90 \mu \mathrm{m}$ fractions, while the contribution in the 10-20 and 20-40 $\mu \mathrm{m}$ fractions ranged from 6 to $30 \%$.

The $<10 \mu \mathrm{m}$ fraction, which in the Gotland Basin was sampled more often than the other fractions, had somewhat lower C:N, C:P and N:P ratios in 1998 (mean \pm
$\mathrm{SE}, 7.7 \pm 0.2,140 \pm 3$ and $18.0 \pm 0.1$, respectively, $\mathrm{n}=5$ ) compared to $1997(8.9 \pm 0.2,171 \pm 4$ and $19.2 \pm 0.2$ respectively, $\mathrm{n}=8$; Mann-Whitney $U$-test, $\mathrm{p}<0.01$ ). This difference was mainly due to particles in the 3-10 $\mu \mathrm{m}$ fraction (Fig. 7).

\section{DISCUSSION}

Inferring nutrient limitation of phytoplankton growth rate from bulk seston stoichiometry is not straightforward. Phytoplankton elemental ratios may be distorted by the presence of terrestrial detritus, which commonly has high C:N and C:P ratios (Hecky et al. 1993). Detritus originating from plankton may also pose a problem, if its $\mathrm{C}, \mathrm{N}$ and $\mathrm{P}$ contents are mineralised at different rates. However, several authors (Harris 1986, Sommer 1989, Hecky et al. 1993) have concluded that the influence of detritus on seston $\mathrm{C}: \mathrm{N}: \mathrm{P}$ ratios is normally minor, or even absent, in large lakes and oceans. We expected little influence from terrestrial detritus, since seston was collected in the open Baltic Sea proper. Here, the water residence time above the halocline is many years (Wulff et al. 2001), while the turnover time of particulate matter is only weeks (estimated from phytoplankton primary production and seston C concentration). It is possible that a high proportion of detritus may explain the high $\mathrm{C}: \mathrm{N}$ and $\mathrm{C}: \mathrm{P}$ ratios found in winter, prior to the onset of the spring bloom (Fig. 5), but we suspect that these ratios may be flawed due to very low seston $\mathrm{C}, \mathrm{N}$ and $\mathrm{P}$ concentrations. During spring and summer, the estimates of biomass indicated that $\sim 40 \%$ of seston $\mathrm{C}$ could be attributed to phytoand bacterioplankton, irrespective of season.

Clear differences in seston stoichiometry between oceans and lakes were demonstrated by Hecky et al. (1993), who concluded that ocean plankton is not as Nor P-deficient as lake plankton. As typical for marine sites, we found average seston element compositions in the upper $20 \mathrm{~m}$ of the brackish northern Baltic Sea proper to be very similar to Redfield ratios during most of the year (mean $\pm \mathrm{SD}, \mathrm{C}: \mathrm{N}=7.2 \pm 0.5, \mathrm{C}: \mathrm{P}=113 \pm 15$, $\mathrm{N}: \mathrm{P}=15.6 \pm 2.0$ ). The largest deviations occurred at the end of the spring bloom (C:N) and near the late summer cyanobacterial biomass peak (C:P and N:P). However, at $5 \mathrm{~m}$ depth, approximately the depth of maximum photosynthesis, ratios were higher than Redfield, indicating depth-related differences within the top $20 \mathrm{~m}$ of water. Much of the summer variability in the DIP concentration in the top $20 \mathrm{~m}$ was related to the position of the summer pycnocline in relation to the lower end of this depth interval (Fig. 3), thus reflecting nutrient conditions in the water below the pycnocline, which was usually rich in DIP and low in DIN. In the deeper parts, light-limited growth and higher nutrient 



Size fraction $(\mu \mathrm{m})$

Fig. 7. Carbon concentrations ( $\left.\mu \mathrm{mol} \mathrm{l}^{-1}\right)$ and molar $\mathrm{C}: \mathrm{N}$ :P ratios in seston size fractions (5 $\mathrm{m}$ depth) at closely situated stations in the eastern Gotland Basin: (A,D) Stn A1, 30 July to 6 August 1997; (B,E) Stn T1, 7 August 1998; and (C,F) Stn BY15, 9 August 1998. Error bars are $(\mathrm{A}, \mathrm{D})+\mathrm{SD}$ of $4(>1,1-3$ and 3-10 $\mu \mathrm{m}), 3(10-20,20-40,40-90 \mu \mathrm{m})$ and $2(>90 \mu \mathrm{m})$ independent fractionations, or $(\mathrm{B}, \mathrm{E})$ range of $2(<1,1-3,3-10 \mu \mathrm{m})$ or $+\mathrm{SD}$ of $3($ all $>10 \mu \mathrm{m})$ independent fractionations

availability will allow phytoplankton to grow under nutrient saturated conditions (Tett et al. 1985), and possibly store nutrients in excess of immediate growth demands.

\section{Spring period}

In spring, significant chl a concentrations (1 to $2 \mu \mathrm{g}$ $\mathrm{l}^{-1}$ ) were observed down to $40 \mathrm{~m}$ depth (data not shown), far below the compensation depth, where photosynthesis equals respiration. Primary limitation by light may explain why the seston elemental composition at first remained close to Redfield ratios, with seston $\mathrm{C}: \mathrm{N}$ close to, and $\mathrm{C}: \mathrm{P}$ and $\mathrm{N}: \mathrm{P}$ only somewhat below the Redfield ratios (Fig. 4). This indicates low nutrient storage capacity of the dominating diatoms and dinoflagellates, or a growth rate high enough to balance nutrient uptake. Only Aphanizomenon sp., which was present in low abundance in spring, accumulated large intracellular P reserves (Fig. 2), probably due to slow growth, limited by temperature and/or light (Walve \& Larsson 2007). Prior to the collapse of the spring bloom, there was a clear but transient increase in the seston C:N ratio in the $0-20 \mathrm{~m}$ layer (to ca. 9, note that samples at $5 \mathrm{~m}$ depth are missing on this occasion, Figs. 4D \& 5D). The high C:N ratio was associated with the spring peak in seston $\mathrm{C}$ concentration, a second peak in phytoplankton biomass (Fig. 2) and an increased seston C:chl a-ratio (Fig. 6). How- 
ever, the ratio of phytoplankton to seston $\mathrm{C}$ remained unchanged, indicating a constant proportion of detritus during this final phase of the spring bloom. A C:N ratio $>9$ can indicate a clear reduction in growth rate (Goldman 1980), and Healey \& Hendzel (1980) suggested a $\mathrm{C}: \mathrm{N}$ ratio $>8$ to indicate moderate $\mathrm{N}$ limitation. $\mathrm{N}$ limitation is consistent with the low DIN:DIP ratios prior to the onset of the spring bloom and the depletion of DIN not only in the top $20 \mathrm{~m}$, as shown in Fig. 3A, but also down to $40 \mathrm{~m}$ depth, while some DIP was left unused. That cells were P-sufficient is clear from the low seston N:P and C:P ratios. There is no indication that grazing caused the collapse of the spring bloom, as there were very few large grazers present, and estimated grazing by ciliates, which peaked in response to the spring bloom, was low relative to phytoplankton production (Johansson et al. 2004). The increased seston $C: N$ ratio in spring was not the result of a shift from diatoms to dinoflagellates, since this shift occurred earlier during the spring bloom. A similar increase in seston C:N ratio (to $\sim 10$ ), was observed by Lindqvist \& Lignell (1997) at the end of a Baltic proper spring bloom, also dominated by dinoflagellates. They demonstrated an unusually high proportion of lipid synthesis in this period, which they assumed to be a response to nutrient limitation since it was reduced by experimental nutrient addition.

\section{Early summer period}

In early summer (May-June), the presence of significant DIP concentrations in the near absence of DIN indicated phytoplankton $\mathrm{N}$ limitation, at least initially. The C:N ratio in the $<3 \mu \mathrm{m}$ fraction was then near Redfield, but later became slightly elevated in the $5 \mathrm{~m}$ samples ( $\mathrm{C}: \mathrm{N} \sim 8$, highest in the $<10$ fraction), indicating weak $\mathrm{N}$ limitation of phytoplankton growth rate according to the criteria of Healey \& Hendzel (1980). Alternatively, it is possible that the $\mathrm{C}: \mathrm{N}$ ratio is relatively rigid for the dominating phytoplankton species (mainly picoplankton $<3 \mu \mathrm{m}$ and small flagellates 3-10 $\mu \mathrm{m})$. However, many studies indicate a high growth and turnover rate of small plankton in nutrient recycling ecosystems (Dugdale \& Goering 1967, Eppley \& Peterson 1979). Control of small phytoplankton biomass mainly by zooplankton and protist grazing, together with the great importance of recycled nutrients from grazers (Sörensson \& Sahlsten 1987), may explain why growth rate limitation by $\mathrm{N}$ is weak, as indicated by elemental $\mathrm{C}: \mathrm{N}$ ratios in the early summer period. Growth rates near maximum, i.e. only slight growth rate nutrient limitation, can also be consistent with nutrient limitation of biomass (Liebig-type limitation) (Goldman et al. 1979). Indeed, nutrient enrich- ment and dilution experiments in the coastal zone of the northern Baltic proper (Lignell et al. 2003) indicate $\mathrm{N}$ limitation of phytoplankton biomass rather than of growth rate during the P-replete early summer period. Lignell et al. (2003) also found low seston C:N and N:P ratios during this period. Lindqvist \& Lignell (1997) likewise found an efficient channelling of fixed carbon into N-rich proteins at this time of year, indicating only slight $\mathrm{N}$ limitation of growth rate.

\section{Late summer period}

From July, seston C:N ratios were somewhat elevated at $5 \mathrm{~m}$ depth (Fig. 5), indicating weak $(<3 \mu \mathrm{m}$ fraction) to moderate $\mathrm{N}$ limitation (3-10 $\mu \mathrm{m}$ fraction). However, starting in late June, C:P and $\mathrm{N}: \mathrm{P}$ ratios at $5 \mathrm{~m}$ depth gradually increased in all size fractions, and reached maximum values at the biomass peak of $\mathrm{N}_{2}$-fixing filamentous cyanobacteria in early September. This could not be attributed directly to filamentous cyanobacteria, since microscopic examination showed that usually much less than $10 \%$ of the filamentous cyanobacterial biomass passed through the $10 \mu \mathrm{m}$ net and that no filaments passed through the $3 \mu \mathrm{m}$ filter. Filamentous cyanobacteria contributed $<1 \%$ to seston $\mathrm{C}$ in the $<10 \mu \mathrm{m}$ fraction. At the cyanobacterial biomass peak, the $<10 \mu \mathrm{m}$ seston C:P ratio at $5 \mathrm{~m}$ depth was 201, which is above the threshold of 129 proposed by Healey \& Hendzel (1980) for moderate P limitation (severe limitation: $\mathrm{C}: \mathrm{P}=258$ ). The $\mathrm{N}: \mathrm{P}$ ratio of 23 in the $<10 \mu \mathrm{m}$ fraction just exceeded the proposed P limitation threshold of 22, and at the same time the $\mathrm{C}: \mathrm{N}$ ratio just exceeded the threshold for moderate $N$ limitation ( $C: N=8.3$; severe $C: N=14.6)$. We suggest that the increase from near Redfield seston $\mathrm{C}: \mathrm{P}$ and $\mathrm{N}: \mathrm{P}$ ratios in fractions $<10 \mu \mathrm{m}$ in early summer to higher ratios in late summer was the result of an increased growth of diazotrophs, which intensified competition for $\mathrm{P}$ following the depletion of the DIP pool. Our data on the chemical composition of filamentous cyanobacteria indicate they are N-sufficient $(\mathrm{C}: \mathrm{N} \leq 6.6)$ throughout their growth period, but become severely P-deficient at the biomass peak (C:P > 400) (see Larsson et al. 2001, Walve \& Larsson 2007). The progressive increase in $\mathrm{P}$ deficiency during their growth period is likely to gradually reduce growth rate to only a few percent of their maximal rate (Healey 1982) at bloom culmination. We argue that $P$ depletion is the likely cause of growth termination, which is supported by nutrient addition experiments by Granéli et al. (1990) and Moisander et al. (2003). Consequently, cyanobacteria will compete fiercely for P, as shown by Nausch et al. (2004), who found much higher plankton $\mathrm{P}$ uptake rates and alkaline phos- 
phatase activity in late summer during cyanobacterial blooms than in early summer.

The competition for $\mathrm{P}$ is further aggravated by the new inputs of combined $\mathrm{N}$ from $\mathrm{N}_{2}$ fixation. New estimates suggest that cyanobacteria supply large amounts of fixed $\mathrm{N}$ to the upper mixed layer during summer (Larsson et al. 2001, Wasmund et al. 2001, 2005, Rolff et al. 2007). Most of this remains in the upper mixed layer and is seen as a build-up of total $\mathrm{N}_{\text {; }}$ this is most likely responsible for the relatively large increase in seston $\mathrm{C}$ and $\mathrm{N}$ concentrations in the fractions $<10 \mu \mathrm{m}$ during the cyanobacterial bloom (Fig. 4). This also indicates that newly fixed $\mathrm{N}$ is made available to other phytoplankton to alleviate their need for $\mathrm{N}$ (C:N ratios only moderately elevated, see below), which is supported by $\mathrm{N}$ isotope measurements of sizefractionated plankton (Rolff 2000, Höglander 2005). Excess fixed $\mathrm{N}$ may be released during growth (Capone et al. 1994, Glibert \& Bronk 1994, Rolff et al. 2007) and/or stem from decomposition of old (high $\mathrm{N}: \mathrm{P})$ cyanobacterial colonies. Generally, most of the cyanobacteria are believed to decompose near the surface rather than being lost through sedimentation (Hoppe 1981, Heiskanen \& Kononen 1994). As a result of the new $\mathrm{N}$ input, competition for $\mathrm{P}$ should increase further and eventually cause the collapse of the cyanobacterial bloom. This is consistent with the results of Lignell et al. (2003), who found a positive response of chl a-normalized ${ }^{14} \mathrm{CO}_{2}$ fixation and growth rates to $\mathrm{P}$ addition, indicating physiological $\mathrm{P}$ deficiency of the whole algal assemblage, during the cyanbacterial bloom. Similar to the present study, Lignell et al. (2003) found a seston N:P ratio during the cyanobacterial bloom of ca. 21 (<40 $\mu \mathrm{m}$ fraction). This ratio decreased to the Redfield ratio when $\mathrm{P}$ was added; however, both $\mathrm{N}$ and $\mathrm{P}$ additions were needed to get a clear biomass response, indicating near colimitation (Lignell et al. 2003).

The results from the eastern Gotland Basin in 1997 and 1998 support the conclusions for the late summer period, and also provide more detailed information (additional seston size fractions). Judging from data in Larsson et al. (2001), we believe that a later stage of the bloom was sampled in 1997 than in 1998. However, the overall picture was very similar between stations and years. In the smallest size fraction $(<1 \mu \mathrm{m})$, elemental ratios were close to Redfield values. Since this should contain mostly heterotrophic bacteria and single-cell picocyanobacteria, with relatively low C:P ratio of heterotrophic bacteria (Fagerbakke et al. 1996), one would expect $\mathrm{C}: \mathrm{P}$ and N:P ratios in picocyanobacteria somewhat above the Redfield ratios, as suggested by Bertilsson et al. (2003). If some picocyanobacterial species are able to fix N (Mitsui et al. 1986, Le Moal \& Biegala 2009) in the Baltic Sea, this is not manifested in clearly elevated C:P and N:P ratios as in the filamentous cyanobacteria. Stal et al. (2003) found filamentous picocyanobacteria in the Baltic Sea, potentially capable of $\mathrm{N}_{2}$ fixation, and Wasmund et al. (2001) reported $\mathrm{N}_{2}$ fixation activity in the $<10 \mu \mathrm{m}$ size-fraction, suggesting $\mathrm{N}_{2}$ fixation by non-heterocystous cyanobacteria. Many heterotrophic bacteria can also fix $\mathrm{N}_{2}$, but their contribution in the upper mixed layer is likely to be minimal since they require low oxygen concentrations when fixing $\mathrm{N}_{2}$ (Boström et al. 2007). Thus, Pdeficient $\mathrm{N}_{2}$-fixing cyanobacteria in the fractions $<10 \mu \mathrm{m}$ could contribute to the summer increases in $\mathrm{C}: \mathrm{P}$ and $\mathrm{N}: \mathrm{P}$ ratios.

Nutrient addition experiments performed on the Gotland Basin cruises also showed rapid uptake of $\mathrm{P}$ also in the smallest seston fractions, resulting in a markedly lowered seston N:P ratio (to below Redfield), especially in 1997 (Kuuppo et al. 2003, J. Seppälä pers. comm.). In 1997, additions of P alone sometimes stimulated phytoplankton biomass and primary production, but generally, combined $\mathrm{N}$ and $\mathrm{P}$ additions were needed, again indicating near co-limitation. $\mathrm{N}$ uptake was small if $\mathrm{P}$ was not added and $\mathrm{P}$ alone sometimes also stimulated bacterial production. In 1998, P deficiency was less pronounced and signs of $\mathrm{N}$ limitation more clear (chl a increase). Our data showed somewhat lower C:N, C:P and N:P ratios in 1998 than 1997 in the $<10 \mu \mathrm{m}$ fraction, supporting a less P-deficient status of phytoplankton in 1998. Co-limitation of $\mathrm{N}$ and $\mathrm{P}$ or transient $\mathrm{P}$ limitation should be most pronounced during well-stratified conditions and at a later stage of the cyanobacterial bloom, as in 1997, with lower P input from deep water and larger $\mathrm{N}$ input from decaying cyanobacteria.

\section{CONCLUSIONS}

In conclusion, the presence of clear $\mathrm{N}$ limitation in spring, indicated by the inorganic nutrient data, is confirmed by changes in the seston $\mathrm{C}: \mathrm{N}$ ratio, but the changes were small and the period of elevated $C: N$ ratio was short. The seston N:P ratio in spring was only slightly lower than the Redfield ratio despite an upper mixed layer DIN:DIP ratio well below the Redfield ratio in winter. Only filamentous cyanobacteria, which accumulate a substantial intracellular $\mathrm{P}$ storage in spring, displayed a very low N:P ratio. The P-replete early summer community also had a seston $\mathrm{N}: \mathrm{P}$ ratio close to the Redfield ratio. In early summer, seston C:N stoichiometry indicated only weak nutrient limitation, probably due to a phytoplankton community of small cells with high turnover rate. In late summer, the high $\mathrm{N}: \mathrm{P}$ ratio indicated that the slow-growing, and relatively little grazed, filamentous diazotrophic cyanobac- 
teria grow into clear $\mathrm{P}$ limitation. Periods of $\mathrm{P}$ limitation, or $\mathrm{N}$ and $\mathrm{P}$ co-limitation, of non-diazotrophs in late summer were probably due to compensation of new $\mathrm{P}$ inputs by $\mathrm{N}_{2}$ fixation, performed by cyanobacteria with a high $\mathrm{N}$ yield relative to $\mathrm{P}$ demand. Still, extensive denitrification and efficient $\mathrm{P}$ recycling in the deep water seem to maintain a low overall N:P ratio in the Baltic proper (Vahtera et al. 2007).

Acknowledgements. We thank our colleagues within the Baltic Sea System Study (BASYS) who supplied unpublished data, especially J. Seppälä, R. Lignell and S. Hajdu, and the staff at the Chemical Analysis Laboratory at our department and the crews of the MS 'Baltica' and the MS 'Fyrbyggaren' for assistance with field sampling. Funding was provided by the EU through BASYS within the MAST III program (MAS3CT96-0058), the Swedish Foundation for Strategic Environmental Research (MISTRA: SUCOZOMA), the Swedish National Marine Environmental Monitoring Program, and the Stockholm Marine Research Centre. Comments by 4 anonymous reviewers and R. Elmgren improved the manuscript.

\section{LITERATURE CITED}

Bertilsson S, Berglund O, Karl DM, Chisholm SW (2003) Elemental composition of marine Prochlorococcus and Synechococcus: implications for the ecological stoichiometry of the sea. Limnol Oceanogr 48:1721-1731

Boström KH, Riemann L, Kühl M, Hagström Å (2007) Isolation and gene quantification of heterotrophic $\mathrm{N}_{2}$-fixing bacterioplankton in the Baltic Sea. Environ Microbiol 9:152-164

Calvo-Díaz A, Morán XAG, Suárez LA (2008) Seasonality of picophytoplankton chlorophyll $a$ and biomass in the central Cantabrian Sea, southern Bay of Biscay. J Mar Syst 72: 271-281

Capone DG, Ferrier MD, Carpenter EJ (1994) Amino acid cycling in colonies of the planktonic marine cyanobacterium Trichodesmium thiebautii. Appl Environ Microbiol 60:3989-3995

> Deutsch C, Sarmiento JL, Sigman DM, Gruber N, Dunne JP (2007) Spatial coupling of nitrogen inputs and losses in the ocean. Nature 445:163-167

Dugdale RC, Goering JJ (1967) Uptake of new and regenerated forms of nitrogen in primary productivity. Limnol Oceanogr 12:196-206

Elser JJ, Chrzanowski TH, Sterner RW, Schampel JH, Foster DK (1995) Elemental ratios and the uptake and release of nutrients by phytoplankton and bacteria in three lakes of the canadian shield. Microb Ecol 29:145-162

Elser JJ, Bracken MES, Cleland EE, Gruner DS and others (2007) Global analysis of nitrogen and phosphorus limitation of primary producers in freshwater, marine and terrestrial ecosystems. Ecol Lett 10:1135-1142

Eppley RW, Peterson BJ (1979) Particulate organic matter flux and planktonic new production in the deep ocean. Nature 282:677-680

Fagerbakke KM, Heldal M, Norland S (1996) Content of carbon, nitrogen, oxygen, sulfur and phosphorus in native aquatic and cultured bacteria. Aquat Microb Ecol 10: $15-27$

Falkowski PG, Davis CS (2004) Natural proportions. Nature 431:131

Glibert PM, Bronk DA (1994) Release of dissolved organic nitrogen by marine diazotrophic cyanobacteria Trichodesmium spp. Appl Environ Microbiol 60:3996-4000

Goldman JC (1980) Physiological processes, nutrient availability, and the concept of relative growth rates in marine phytoplankton ecology. In: Falkowski PG (ed) Primary productivity in the sea. Plenum Press, New York, NY, p 179-194

Goldman JC, McCarthy JJ, Peavey D (1979) Growth rate influence on the chemical composition of phytoplankton in oceanic waters. Nature 279:210-215

Granéli E, Wallström K, Larsson U, Granéli W, Elmgren R (1990) Nutrient limitation of primary production in the Baltic Sea area. Ambio 19:142-151

Harris GP (1986) Phytoplankton ecology: structure, function and fluctuation. Chapman and Hall, London

Healey FP (1982) Phosphate. In: Carr NG, Whitton BA (eds) The biology of cyanobacteria. Botanical Monographs Vol 19. Blackwell Scientific, Oxford, p 105-125

> Healey FP, Hendzel LL (1980) Physiological indicators of nutrient deficiency in lake phytoplankton. Can J Fish Aquat Sci 37:442-453

Hecky RE, Kilham P (1988) Nutrient limitation of phytoplankton in freshwater and marine environments: a review of recent evidence on the effects of enrichment. Limnol Oceanogr 33:796-822

Hecky RE, Campbell P, Hendzel LL (1993) The stoichiometry of carbon, nitrogen and phosphorus in particulate matter of lakes and oceans. Limnol Oceanogr 38:709-724

Heiskanen AS, Kononen K (1994) Sedimentation of vernal and late summer phytoplankton communities in the coastal Baltic Sea. Arch Hydrobiol 131:175-198

HELCOM (Helsinki Commission) (1988) Guidelines for the Baltic Monitoring Programme for the third stage; Part D. Biological Determinants. Balt Sea Environ Proc 27D:1-161

Hochstädter S (2000) Seasonal changes of C:P ratios of seston, bacteria, phytoplankton and zooplankton in a deep, mesotrophic lake. Freshw Biol 44:453-463

Höglander H (2005) Studies of Baltic Sea plankton: spatial and temporal patterns. PhD dissertation, Stockholm University

Hoppe HG (1981) Blue-green algae agglomeration in surface water: a microbiotope of high bacterial activity. Kiel Meeresforsch Sonderh 5:291-303

Howarth RW (1988) Nutrient limitation of net primary production in marine ecosystems. Annu Rev Ecol Syst 19:89-110

Johansson M, Gorokhova E, Larsson U (2004) Annual variability in ciliate community structure, potential prey and predators in the open northern Baltic Sea proper. J Plankton Res 26:67-80

Kahru M, Savchuk OP, Elmgren R (2007) Satellite measurements of cyanobacterial bloom frequency in the Baltic Sea: interannual and spatial variability. Mar Ecol Prog Ser 343: $15-23$

Karl D, Michaels A, Bergman B, Capone D and others (2002) Dinitrogen fixation in the world's oceans. Biogeochemistry 57-58:47-98

$>$ Klausmeier CA, Litchman E, Daufresne T, Levin SA (2008) Phytoplankton stoichiometry. Ecol Res 23:479-485

Kuuppo P, Samuelsson K, Lignell R, Seppälä J, Tamminen T, Andersson A (2003) Fate of increased production in latesummer plankton communities due to nutrient enrichment of the Baltic Proper. Aquat Microb Ecol 32:47-60

Larsson U, Hajdu S, Walve J, Elmgren R (2001) Baltic nitrogen fixation estimated from the summer increase in upper mixed layer total nitrogen. Limnol Oceanogr 46:811-820

Le Moal M, Biegala IC (2009) Diazotrophic unicellular cyanobacteria in the northwestern Mediterranean Sea: a sea- 
sonal cycle. Limnol Oceanogr 54:845-855

Lignell R, Seppälä J, Kuuppo P, Tamminen T, Andersen T, Gismervik I (2003) Beyond bulk properties: responses of coastal summer plankton communities to nutrient enrichment in the northern Baltic Sea. Limnol Oceanogr 48:189-209

Lindqvist $\mathrm{K}$, Lignell R (1997) Intracellular partitioning of ${ }^{14} \mathrm{CO}_{2}$ in phytoplankton during a growth season in the northern Baltic. Mar Ecol Prog Ser 152:41-50

Mitsui A, Kumazawa S, Takahashi A, Ikemoto H, Cao S, Arai $\mathrm{T}$ (1986) Strategy by which nitrogen-fixing unicellular cyanobacteria grow photoautotrophically. Nature 323: $720-722$

Moisander PH, Steppe TF, Hall NS, Kuparinen J, Paerl HW (2003) Variability in nitrogen and phosphorus limitation for Baltic Sea phytoplankton during nitrogen-fixing cyanobacterial blooms. Mar Ecol Prog Ser 262:81-95

Nausch M, Nausch G, Wasmund N (2004) Phosphorus dynamics during the transition from nitrogen to phosphate limitation in the central Baltic Sea. Mar Ecol Prog Ser 266: $15-25$

Niemi Å (1979) Blue-green algal blooms and N:P ratio in the Baltic Sea. Acta Bot Fenn 110:57-61

Rahm L, Jönsson A, Wulff F (2000) Nitrogen fixation in the Baltic proper: an empirical study. J Mar Syst 25:239-248

Redfield AC, Ketchum BH, Richards FA (1963) The influence of organisms on the composition of sea water. In: Hill MN (ed) The sea, Vol II. Interscience Publishers, New York, NY, p 26-77

Rolff C (2000) Seasonal variation in $\delta^{13} \mathrm{C}$ and $\delta^{15} \mathrm{~N}$ of size-fractionated plankton at a coastal station in the northern Baltic proper. Mar Ecol Prog Ser 203:47?65

Rolff C, Almesjö L, Elmgren R (2007) Nitrogen fixation and abundance of the diazotrophic cyanobacterium Aphanizomenon sp. in the Baltic Proper. Mar Ecol Prog Ser 332: $107-118$

Rolff C, Elmgren R, Voss M (2008) Deposition of nitrogen and phosphorus on the Baltic Sea: seasonal patterns and nitrogen isotope composition. Biogeosciences 5:1657-1667

Sjöberg B, Larsson U (1996) Hydrografi och näringsämnen. In: Tidlund A, Henkow M (eds) Östersjö '95. Available at www.smf.su.se/nyfiken/ostersjo/ostersjo95.html (in Swedish)

Sommer U (1989) The role of competition for resources in phytoplankton succession. In: Sommer U (ed) Plankton ecology: succession in plankton communities. SpringerVerlag, Berlin

Sommer U (1991) A comparison of the Droop and the Monod models of nutrient limited growth applied to natural populations of phytoplankton. Funct Ecol 5:535-544

Sörensson F, Sahlsten E (1987) Nitrogen dynamics of a cyanobacterial bloom in the Baltic Sea: new versus regenerated production. Mar Ecol Prog Ser 37:277-284

Stal LJ, Albertano P, Bergman B, von Brockel K and others (2003) BASIC: Baltic Sea cyanobacteria. An investigation of the structure and dynamics of water blooms of cyano bacteria in the Baltic Sea-responses to a changing environment. Cont Shelf Res 23:1695-1714

Tett P, Heaney SI, Droop MR (1985) The Redfield ratio and phytoplankton growth rate. J Mar Biol Assoc UK 65: 487-504

Tyrrell T (1999) The relative influences of nitrogen and phosphorus on oceanic primary production. Nature 400: $525-531$

Vahtera E, Conley DJ, Gustafsson BG, Kuosa H and others (2007) Internal ecosystem feedbacks enhance nitrogenfixing cyanobacteria blooms and complicate management in the Baltic Sea. Ambio 36:186-194

- Walve J, Larsson U (1999) Carbon, nitrogen and phosphorus stoichiometry of crustacean zooplankton in the Baltic Sea: implications for nutrient recycling. J Plankton Res 21: $2309-2321$

- Walve J, Larsson U (2007) Blooms of Baltic Sea Aphanizomenon sp. (Cyanobacteria) collapse after internal phosphorus depletion. Aquat Microb Ecol 49:57-69

> Wasmund N, Voss M, Lochte K (2001) Evidence of nitrogen fixation by non-heterocystous cyanobacteria in the Baltic Sea and re-calculation of a budget of nitrogen fixation. Mar Ecol Prog Ser 214:1-14

> Wasmund N, Nausch G, Schneider B, Nagel K, Voss M (2005) Comparison of nitrogen fixation rates determined with different methods: a study in the Baltic Proper. Mar Ecol Prog Ser 297:23-31

Wulff F, Rahm L, Hallin AK, Sandberg J (2001) A nutrient budget model of the Baltic Sea. In: Wulff F, Rahm L, Larsson P (eds) A systems analysis of the Baltic Sea. Ecological Studies 148. Springer-Verlag, Berlin, p 353-372

Submitted: January 20, 2009; Accepted: February 19, 2010 Proofs received from author(s): May 3, 2010
Editorial responsibility: Matthias Seaman,

Oldendorf/Luhe, Germany 